\title{
TRADITIONAL VALUES IN THE FUNCTION OF PROMOTION OF ŠUMADIJAAND POMORAVLJE AS RURAL TOURISM DESTINATIONS
}

\author{
Marija Mandarićl', Snežana Milićević ${ }^{2}$ Dejan Sekuliç
}

\begin{abstract}
Summary
Rural tourism and diversification of economic activities are now an integral part of sustainable development of rural areas and regions of Šumadija and Pomoravlje. Development of rural tourism improves the economic position and social activity of the population of rural areas. Šumadija and Pomoravlje region has significant natural and human resources for the development of rural tourism, which have not been adequately utilized. The preservation of authentic values of climate, especially of traditional crafts and gastronomy, can contribute to the development and recognition of the region as a new destination for rural tourism in Serbia. Traditional products due to their features, quality and heritage, can become a regional brand, and also promote the region as a unique destination of rural tourism. The aim of the paper is to explore the representation of traditional crafts, production of handicrafts and traditional cuisine in the region of Sumadija and Pomoravlje. The results of the research conducted point to a significant and under-utilized potential of traditional values in the development and promotion of the region as a rural tourism destination.
\end{abstract}

Keywords: rural tourism, traditional values, brending, tourist destination, Šumadija and Pomoravlje.

JEL: D12, M21, M31, Q13, Z32

\section{Introduction}

Many authors state that tourism has a significant impact on the economic, sociocultural, ecological and functional development of rural areas. Rural tourism is an

1 Marija Mandarić Ph.D., Assistant Professor, University of Kragujevac, Faculty of Hotel Management and Tourism in Vrnjačka Banja, Vojvođanska Street nn, Vrnjačka Banja, Serbia, Phone: +381642590099, E-mail: mmandaric@kg.ac.rs.

2 Snežana Milićević Ph.D., Assistant Professor, University of Kragujevac, Faculty of Hotel Management and Tourism in Vrnjačka Banja, Vojvođanska Street nn, 36210 Vrnjačka Banja, Serbia, Phone: +381648198991, E-mail: snežana.milićević@kg.ac.rs.

3 Dejan Sekulić M.Sc., Teaching Assistant, University of Kragujevac, Faculty of Hotel Management and Tourism in Vrnjačka Banja, Vojvođanska Street nn, 36210 Vrnjačka Banja, Serbia, Phone: +38162602902, E-mail: dejan.sekulic@kg.ac.rs.

EP 2017 (64) 2 (787-803) 
essential factor in the revitalization and diversification of the rural economy (Buhalis and Costa, 2006; Cozac, 2012; Saarinen, Lenao, 2014, Ristić, Vujičić, Leković, 2016). The economic aspect of the rural tourism development is reflected in the employment of the rural population and opening of new jobs, increase the living standard of the local population, i.e. increase of rural incomes and creating a prosperous rural economy (Boyne, 2005; Mitchell, Hall, 2005; Schubert, Brida, Risso, 2011). Socio-cultural aspect is reflected in the revitalization of local (old) crafts, customs and cultural identity. In addition, rural tourism contributes to the interaction of tourists from urban places and towns with rural residents and rural areas (Košić, Demirović, Pejanović, Lazić, Stamenković, 2015). The ecological function of rural tourism is reflected in the improvement and enhancement of the quality of the rural environment, as well as protection of natural beauties and eco-system (Liu, 2002). Although it is general opinion that for application of ecological standards capital investments are needed, it should be noted that majority of them are organizational and may be easily and quickly applied. The fact certainly highlights the need for training managerial structures in facilities, as well as the information for the guests to make them aware of ecologically responsible business advantage. Possible educational brochures would aim at directing the guests to perceive environmental problems and make joint efforts to help preserve the environment. (Bradić, Kosar, Djeri, Vukosav, Garača, 2017).

Recently, there is great interest in old crafts and tools as a very attractive form of tourism offer. The possibility to present all the contents in the countryside related to the life and work of the local people, which have long since been forgotten and abandoned, is a great tourist potential. In that way the tourism offer could be completed, and for the people from highly urbanized industrial centers would be a special attraction. Also, the variety of folk handicrafts may seem quite exotic and attractive to foreign tourists. Almost every rural place can boast with some of its typical products, which occurs as a work hard-working hands of residents of the region. Handicraft is the privilege of the inhabitants of rural areas, which invest their time, skill and sense of beauty in such products. Products of folk art can become a basis for the development of specific industry branch (Vuković, Cecić, Cvijanović, 2007b).

Tradition, handicrafts, folk art, home-made products and traditional gastronomy make a specific region authentic and provide recognition of the destination. Promotion of traditional products and services can be improved by specific slogans, symbols, legends and other. By creating a unique identity features of a regional brand and building a good reputation of the destination itself, it can be contributed to a better definition of national brand and promotion of the region and the country in the world.

Šumadija and Pomoravlje region has a significant natural, anthropogenic and human potential for the development of rural tourism, which has not been adequately utilized. From a total of 366 settlements which the region covers, even 353 are rural settlements. If we add the fact that, of the total population in the region, more than $43 \%$ makes the rural population and that in it there are nearly 52,000 registered farms, it refers to a huge unutilized potential for the development of rural tourism. Authentic traditional values of this region can itself be a regional brand, but also contribute to promoting the region as a unique destination of rural 
tourism. In order to achieve this, greater institutional support is necessary to rural hosts and local associations "guardians of tradition" in rural areas, to be more actively involved in the development of rural tourism.

\section{Methodology and data sources}

For the collection of primary data in this study the survey method, or e-mail survey is used. In addition to the two identification questions, the questionnaire included 23 questions, which can be divided into three groups and were designed based on the research objectives. The study explored the attitudes of respondents who are actively involved in the activities of organization, production and sales of traditional handicrafts, food and beverage and the development of rural tourism in this particular area.

The first group includes 10 questions related to the representation and forms of traditional (old) crafts, organization and method of selling handicrafts. Respondents were asked to answer the dichotomous questions and questions with multiple choice answers.

The second group of questions included 6 questions relating to the organization, the production and sale of traditional foods and beverages. Dichotomous questions and questions with multiple choice answers were present.

The third group is defined by means of 8 questions relating to the degree and the potential of rural development. Respondents were asked to answer the dichotomous questions and questions with multiple choice answers.

\section{Rural tourism}

The initial beginnings of rural tourism development are associated with the distant past when the privileged social classes spent their leisure time in rural areas (Vuković, Arsić, Cvijanović, 2010). Rural areas represent a high potential for tourism development. They are characterized by natural areas, which have their own characteristics: natural landscapes, anthropological achievements, building styles in architecture, customs, traditions and languages (Hrabovski Tomić, 2008). The main characteristics of rural areas are (Čikić, Jovanović, 2015):

- Relatively low density of population and objects in balance with the landscape;

- Economic utilization of space with the dominant purposes in agriculture, forestry and cattle breeding;

- Specific way of life of the population which is characterized by belonging to small communities, and a specific relationship to the area;

- Identity and representation which strongly connote to the rural culture.

In the literature are represented the different interpretations of the concept of rural tourism and its manifest forms, which is determined by the characteristics of the rural area and the availability of resources for the development of rural tourism (Milićević, Podovac, Cavlin, 2015). Uniformity and monotony of everyday life in urban areas has conditioned the need of people to spend some time in a peaceful and healthy environment. Owing EP 2017 (64) 2 (787-803) 
to the natural, ecological and environmental characteristics, different rural areas are a very interesting and promising area for the development of this specific type of tourism (Vukovic, Cecic, Cvijanovic', 2007a). Rural tourism involves tourists' stay in rural areas, who want to make contact with nature, get to know the culture and tradition of the place in which they live, but also to participate in the daily activities of the rural population (Milićević, Đorđević, 2016). Rural tourism can also be defined as a set of activities, services and additional contents, organized by the hosts on family households in order to attract tourists and create additional income, respecting the principles of sustainable development and conservation of natural resources (Mijatov, 2012; Muhi, 2013). Fleischer and Pizam (1997) emphasize the economic aspect of the development of rural tourism and define it as a vacation, during which the tourists most of their free time use for dealing with recreational activities at the farm, ranch, country home or its surroundings. For the host it is a commercial activity, which opens the doors to their homes and property to guests in order to enjoy in recreational activities in a predominantly rural area and to charge a certain price. The primary motives for tourists to come to the countrysideare the nature and cultural heritage, as well as gastronomy, activities, special interests. (Đenadić, Muhi, Jovanović, 2016). Todorović and Štetić (2009) suggest that the definition of rural tourism based on the experience starts from the fact that tourists come into contact with the rural and natural areas, with rural events or goods of rural heritage.

The attractiveness of rural areas is the basis for development of tourist offer of rural tourism destination. Bearing in mind that the villages are ecologically and environmentally preserved integrities, it is a sustainable form of tourism, which contributes to the development of rural economy. Villages that foster traditional values are of attractive tourist destinations (Milićević, Podovac, Čavlin, 2015). Rural tourism includes factors of attractiveness such as (World Tourism Organization, 2004):

- History and archeology (monasteries, old buildings, etc.);

- Cultural heritage (language, traditions, music, dance, handicrafts and so on.);

- Natural attractiveness (attractive sceneries, preserved nature);

- Active vacation (hiking, biking, hunting, etc.).

Wine tourism also could be an important channel for attracting tourists and developing rural areas. This type of tourism is located outside city centers, so it has a positive effect on the economic development of rural areas which are involved in the production of wine. Modern tourists look for authenticity and a unique experience while visiting a certain tourist destination (Sekulić, Mandarić, Milovanović, 2016). One of the features of the modern tourist market is that the unique products are highly appreciated and that today's tourist tends to escape from uniformity offered by globalization and modern lifestyle. In this sense, as an integral part of the tourism offer local, regional and national is increasingly being promoted. Seen from this point of view, the role of the rural households is getting stronger (Vuković, Cecić, Cvijanović, 2007b). 


\section{Destination branding in the function of tourism development}

In the modern world, where today there are over seven billion people, creating a brand destination is a challenge to national or macro-economic aspect. The Republic of Serbia, the present problems such as the low standard of living, unemployment and underdeveloped infrastructure, are essential characteristics of both urban and rural areas. The need to attract tourists, to find new tourist attractions and to offer a unique positive experience, requires that all makers of tourist offer consciously approach the process of branding. Success in attracting tourists is determined by the strategic approach to branding.

Using the branding strategy original or unique recognition of products, services, person or a group of people, concepts, business models, companies or institutions is achieved and offer is differentiated from the competition. Holders or manifestations of the brand can be people, objects, geographical destinations, goods, services and the like. Brand has became the association of a strong identity and global success regardless of the holder in question. Accepted both, in practice and in the marketing literature, that each superior product may be a brand. All organized and individual activities can take on a characteristic of the product and all that is worth, draws attention, has superior and unique characteristics may and it is preferable to be a holder of the brand. The confidence of the wider public determines the strength and success of brands (Mandarić, 2016).

Cities, rural areas, regions and countries around the world are faced with increasing competition between destinations (places) which can be seen in various areas through the struggle: for resources, selling products and services, business operations, as well as for tourists, visitors and even residents. Economic and cultural globalization and increasing competition have caused interest among experts for the implementation of the principles of brand management in the tourism industry in order to develop brand destination. Significant qualitative changes in the tourism market, have made it more competitive in recent years. With the development of the destination brand, tourists are enabled to more easily identify the distinctive advantage of tourism products and services provided at a specific destination in relation to competitors. On the other hand, the branding of typical products at a destination, enables a transfer and overflow of the image to a specific destination.

Branding encourages positive association to a specific geographic location and creates a positive image of the destination in order to attract more visitors. Geographical territories and rural areas as carriers of the brand can have a huge impact on the development of tourism and economic activity of a region or country. Territorial marketing is studied as a special discipline in the developed countries, where each region is approached with special care, both in the economic and tourist sense. It is not possible to change the name of territory and sites, but it is possible to customize the branding strategy, so that it promotes local values in the awareness of the general public. Traditional products and services from a specific destination should be improved by slogans, symbols, legends, with the aim of better promoting the region both at domestic and foreign markets.

Destination brand can be defined as a name, symbol, logo and/or other graphics that serves to identify and distinguish the destination in relation to competition. It gives a promise of 
unforgettable experience of travelling to certain destination for potential visitors and it also serves to strengthen and improve memories of nice experiences, for those who have already been there (Mandarić, Milićević, 2016). Marketing destinations "includes all activities and processes associating vendors and customers, focusing on the response to the demands of consumers and the competitive positioning; it is a continuous set of activities associated with the effective distribution of products to markets with strong potential; involves making decisions about the product, branding, pricing, market segmentation, promotion and distribution" (Veljković, 2010). Brand management can be an important component of building, positioning and strengthening the competitive position of tourist destinations. Modern brand management also incorporates the emotional component of brand development, which is in favor of building a destination brand and enables building strong ties between tourists and the destination. Branding contributes to strengthening the competitive position of the destination itself, makes it easier to overcome the geographical distance, winning new and retaining existing tourists and visitors with revenue growth.

Comprehensive branding is crucial for each country that plans to promote the tourism and increase the attraction of its tourism products. Even if the majority of tourism destinations in the market look a lot like each other, have good conditions for the stay, stress the uniqueness of own culture and heritage, perception of a certain destination must be different. The aim of branding tourism destination is to create a perception in the mind of consumers that there is not a single similar destination in tourism market, that it is special and it should be remembered as entirely unique (Mandarić, Milićević, 2016). Precisely, rural areas can use their potential from the historical and cultural aspect to get better positioned through the offer which will include an authentic environment, the preservation of tradition and unique experience. Branding actually does not happen in the market, but in the minds of consumers, i.e. tourists.

In creating the destination brands legends, (quasi) historical myths, customs, culture, events, traditional food and drink, handicrafts, concern about the protection of the environment, followed by music, colors, symbols, etc. can be used. The image of local, regional and national brands affects the image of the country, and vice versa. The image of the country affects the attitudes towards national products and services and enables attracting investment, jobs and tourists. It affects the consumers' decisions about purchasing, investments, change of residence and travels. Taking into account that the image of the country is under the strong influence of the past, a longer period of timeis needed for its repositioning. The brand image of a state (nation) can be defined as a set of impressions and beliefs that people have about some place or country. The image represents a large number of associations and information related to a particular state or nation. The process of thinking makes it possible to collect and process all the necessary information from large amounts of data about a place (country) (Kotler, Ph., D. Gertner, 2002). By building strong local, regional and national brands one can despite the positive economic effects for the population and building awareness and brand identity, achieve a number of benefits for tourists in terms of reducing the perceived risk, strengthening the emotional connection with the destination and unforgettable experience with the destination. 


\section{The potential of Šumadija and Pomoravlje for the development of rural tourism}

Šmadija and Pomoravlje region is located in the central part of the Republic of Serbia, between the great rivers Sava and Danube in the north, the Great Morava in the east, West Morava and Kolubara in the south west. The region covers an area of $5.002 \mathrm{~km}^{2}$, which is approximately $5.6 \%$ of the total area of the Republic of Serbia. On this territory, according to the latest data of the Statistical Office of the Republic of Serbia, there is a total population of 494,275, while the average population density is about 100 inhabitants $/ \mathrm{km}^{2}$. The share of the population of Šmadija and Pomoravlje in the total population of Serbia is approximately $7 \%$.

The region Šumadija and Pomoravlje in its composition includes two districts Šumadija and Pomoravlje. Šumadija district includes the city of Kragujevac and six municipalities: Arandjelovac, Batočina, Lapovo, Knić, Raća and Topola. The total area of Šumadija district is $2,388 \mathrm{~km}^{2}$ of which $835 \mathrm{~km}^{2}$ is the territory of the city of Kragujevac, which is also the largest city of the region. Population of Šmadija district is 287,784 inhabitants, while the average population density is 121 inhabitant/ $\mathrm{km}^{2}$. Pomoravlje district is comprised of the town Jagodina and five municipalities: Despotovac, Paraćin, Rekovac, Svilajnac i Ćuprija. With a total of $2,614 \mathrm{~km}^{2}$ total area and population of 206,491, Pomoravlje district has an average population density of 79 inhabitants $/ \mathrm{km}^{2}$ (Statistical Office of the Republic of Serbia, Municipalities and regions of the Republic of Serbia, 2016).

Šmadija and Pomoravlje are located in the central part of the Republic of Serbia and thus its position has historically gained the title of a traffic intersection of Serbia. As the main roadways the following should be mentioned: the international corridor A10 which passes along the entire territory, the network of main roads which connect Šumadija and Pomoravlje with the other parts of Serbia, as well as the rail network with shunting station in Lapovo, which belongs to the railway routes that lead to the south, to Montenegro, Bulgaria and Greece and to the north, towards Hungary and Romania (Sustainable Development Strategy for Šumadija and Pomoravlje Region, 2011-2021).

Šumadija and Pomoravlje are characterized by a moderate - continental climate, which is microclimately uneven, mainly due to the height difference between the individual parts of the region. Region characterized by lower rainfall, and is classified as "drier" areas of the Republic of Serbia. The mountains are more moist (about 1,000 mm) per year, and the winds blow from all directions, and the strongest winter wind is Kosava. In terms of geographical characteristics, it can be said that the whole area of Šumadija and Pomoravlje has the characteristics of highland areas with the exception of Moravian valley with its alluvial characteristics. The most attractive mountains are: Rudnik (Cvijić's peak $1.132 \mathrm{~m}$ ), Beljanica (1.339 m), Bukulja (696 m), Vujan (857 m), Juhor (773 m) and Gledić mountains $(922 \mathrm{~m})$. The flora of these mountains is characterized by oak and beech forests at lower altitudes and pine forests at higher altitudes. The fauna is diverse, from small game (rabbit, fox, pheasant, partridge, etc.) to large game (deer, wild boar, etc.) (Regional Agency for Economic Development Šumadije and Pomoravlje, 2016). 
Natural conditions of Šumadija and Pomoravlje region are suitable for development of different agricultural systems. Alluvial plains in river valleys favor the development of field and vegetable crops, and the hillside favor the development of viticulture and fruit growing. The land is mainly used for arable land, orchards and vineyards, but there are some meadows, pastures and forest areas. Owing to its favorable geological and climatic conditions the agricultural production has always been one of the leading sectors in the structure of business activities characterizing Šmadija and Pomoravlje. The total agricultural area in the territory of Sumadija and Pomoravlje region is 329,962 ha. In the structure of the agricultural area dominate the areas under the cereals referring to $41.2 \%$ of the total agricultural area of the region (Sustainable Development Strategy for Šumadija and Pomoravlje Region, 2011-2021).

According to the Regional Economic Development Agency for Šumadija and Pomoravlje, this region has a total of 366 settlements (with the seats of the municipalities). More specifically, the region of Sumadija and Pomoravlje is territorially and administratively subdivided into 2 cities (Kragujevac and Jagodina), and 11 municipalities (Batočina, Lapovo, Rekovac, Arandelovac, Topola, Svilajnac, Knić, Paraćin, Rača, Despotovac, Ćuprija) with a total of 366 populated areas (353 villages and 13 administrative seats of towns and municipalities). According to the census of 2011, of the total population in the region of Sumadija and Pomoravlje, even 43,36\% is rural population. On the territory of Pomoravlje there are 24,990 registered farms, and in the territory of Šmadija District 26.941 (Statistical Office of the Republic of Serbia, Municipalities and regions of the Republic of Serbia, 2016).

In addition to basic agricultural activities on farms, we must also mention the other profitable activities related to rural farms that bring income: meat processing, milk processing, fruit and vegetable processing, processing of other agricultural products, woodworking, forestry activities, tourism, handicrafts, etc. On this basis, even 4,934 households realize additional income. From the reported number, only 34 households $(0.69 \%)$ are engaged in tourism, and 101 household are engaged in domestic handicraft (2.05\%) (Table 1). Engaged in processing of milk, meat, fruit and vegetables are 4,042 households $(81.92 \%)$, which is certainly a potential for local food production to meet the needs of rural tourism (Statistical Office of the Republic of Serbia, Census of Agriculture 2012, Agriculture in the Republic of Serbia).

Table 1. Households with other profitable activities related to the farm in the region of Šumadija and Pomoravlje (2012)

\begin{tabular}{|l|l|l|l|}
\hline Region & Total agricultural households & Tourism & $\begin{array}{l}\text { Domestic } \\
\text { handicraft }\end{array}$ \\
\hline District Šumadija & 3.109 & 23 & 41 \\
\hline District Pomoravlje & 1.825 & 11 & 60 \\
\hline Šumadija i Pomoravlje & 4934 & 34 & 101 \\
\hline
\end{tabular}

Source: Statistical Office of the Republic of Serbia, Census of Agriculture 2012, Agriculture in the Republic of Serbia 
Šumadija and Pomoravlje district have very favorable conditions for the development of rural tourism. In all the villages of Šumadija and Pomoravlje, apart from exceptionally beautiful landscapes and authentic traditional rural households, there are natural and very attractive natural and anthropogenic motifs which can be tourist valorized. The advantages are preserved architecture and organization of traditional farms, old crafts, customs, traditional gastronomy (food and drink), the hospitality and cordiality of the hosts. This type of tourism, which can be one of the directions of development and diversification of agricultural production, is the most developed in the villages in the municipality of Knić, while a significant trend in the development of rural tourism in recent years is noticeable in the municipalities of Rekovac, Kragujevac, Jagodina and Arandjelovac. According to the data of the Regional Agency for economic development of Šumadija and Pomoravlje, on the territory of Šumadija and Pomoravlje region there are several registered ethnic households: in Knić (9), Arandjelovac (3), Despotovac (3), Jagodina (1) and in Lapovo (1).

The municipalities Rača, Ćuprija, Rekovac, Batoćina, Paraćin and Svilajnac have no categorized rural households, which represents $53,85 \%$ of the total number of the municipalities in the region. It points to the enormous natural and human potential that these municipalities have, and that is not adequately utilized for the development of rural tourism. One reason is institutional support, i.e. the capacity of local TO of providing support to rural householders, local women's associations and associations of traditional crafts in rural areas. An integral part of the rural tourism are also the traditional crafts which, in addition to preserving the identity of rural areas can bring significant income for rural population. On the territory of Šumadija-Pomoravlje region, a special role in the preservation of traditional crafts can have women's associations. Currently on the territory operate 9 associations, of which the following should be noted: Association of Women Ethno forma from Jagodina, Ethno association Golden Hands Batočina, Association of Ravno Women from Ćuprija and Moravia iris from Lapovo (Regional Agency for Economic Development Šumadije and Pomoravlje, 2016).

In order to support the preservation and promotion of traditional crafts, the Ministry of Economy of the Republic of Serbia conducts the certifying activities in the field of traditional crafts (old and artistic crafts and handicrafts - the mark of open hand). Also defined are the Rules on the determination of the services that are considered old and artistic crafts, i.e. handicrafts business, mode of certification and keeping a special record on the issued certificates. Certification is one of the mandatory conditions for applying for the funds Ministry of Agriculture and Environmental Protection (Ministarstvo privrede Republike Srbije, 2017). In the region of Šmadija and Pomoravlje there are certified entrepreneurial activities, which represents an additional potential for rural development and tourism. Previous researches indicate that the introduction of eco-labels (through Ecoaccommodation label) could have positive effect on the number of accommodation facilities and competitive advantage at the market (Bradić, Kosar, Djeri, Vukosav, Garača, 2017). It is necessary to consider the possibility for preservation of authentic natural values, traditional crafts and gastronomy by introduction of eco-labeling in order to improve sustainable rural development of the region. 
In addition to numerous opportunities, there are also problems that hinder the development of rural tourism. Countryside is now being challenged as never before by issues of agricultural restructuring, declining service provision, depopulation and counter-urbanization, communication and infrastructural deficits and by the degradation of the natural environment In Serbia, rural households are playing an important part in social and cultural development of rural destinations. However, rural households usually have problems with the lack of money for promotion and also have a problem to adjust to the current market situation, which is dominated by means of modern communication and technology (Dimitrovski, Todorović, Valjarević, 2012). Therefore, in addition to the financial support of state authorities and local governments, it is necessary to educate the population of rural areas with the aim to support entrepreneurial initiatives of individuals and promote the tradition in order to develop rural.

\section{Results and Discussion}

The survey was conducted in January-February 2017. From a total of 13 municipalities in Šmadija and Pomoravlje region, the questionnaires were received from 9 municipalities, completed by tourist organizations (72.7\%), department of municipal administration (18.2\%) and associations (19.1\%).

The results of the descriptive analysis show the following. It was found that in $81.8 \%$ of the municipalities traditional handicrafts using old techniques is developed. According to the technique of production, equally and most represented are embroidery and knitting $38.1 \%$, weaving slightly under $19 \%$, and pottery with only $4.8 \%$. Only $27,3 \%$ of municipalities have organized production of handicrafts. The most common form of organization is through the associations (50\%), then as individuals (37.5\%) through informal groups (12.5\%). In $45.5 \%$ of the municipalities provided by the municipality, is a common area for work. It is interesting that $27.3 \%$ of the surveyed municipalities have preserved old and artistic crafts that have been certified by the Ministry of Economy (with the sign of open hand).

The results showed that in $63.6 \%$ of the municipalities local production of traditional food and drinks is developed, but only in $18.2 \%$ of the municipalities there is an organized sale of food and beverages. In the structure of the sale method, the most common are fairs $(75 \%)$, then the street vendors $(16,7 \%)$ and at least stores $(8.3 \%)$, which is understandable, considering the complexity of the procedures and cost of placement of food and beverages in retail. In accordance with the macro trends of continuing education, education of producers of local products (crafts, food and beverages) has been organized so far and providers of tourist services in $54.5 \%$ of the municipalities, and the general training on entrepreneurship, marketing and sales and foreign languages was dominant with $87.5 \%$, and a specialized (topical) training that included weaving, embroidery, goldwork, wool pressing techniques and similar were significantly less common with only $12.5 \%$.

The support of local government to promote rural development (diversification of economic activities) and rural tourism (including a tourist organization) the respondents rated as excellent in only $27.3 \%$ of cases, satisfactory $54.5 \%$ and inadequate in $18.2 \%$ of cases. Utilization potential of the municipality for rural development and tourism, according to the foregoing, 
was rated to be insufficient in $81.8 \%$ of municipalities, as satisfactory in $18.2 \%$, while no one has stated excellent utilization, which leaves considerable room for improvement.

Considering that the questions were categorial (except the last one), for determining dependencies between the individual frequency of responses to questions, the Chi-square test or Fisher's test were used (with the proviso that the dependence is statistically significant if $\mathrm{p}<0.05)$.

Table 2. Statistical significant correlation obtained by Chi-square test

\begin{tabular}{|c|c|c|c|c|}
\hline & & \begin{tabular}{|l|} 
Chi- \\
square \\
statistics
\end{tabular} & $\begin{array}{l}\text { Number of } \\
\text { degrees of } \\
\text { freedom }\end{array}$ & p \\
\hline 1. & $\begin{array}{l}\text { The production techniques of handicrafts (embroidery, } \\
\text { knitting, weaving, pottery) / Form of organizing the } \\
\text { producers of craft (cooperatives, associations, a craft shop, } \\
\text { informal groups, individuals) }\end{array}$ & 9,321 & 4 & 0,034 \\
\hline 2. & $\begin{array}{l}\text { The techniques of making handicrafts / The manner of } \\
\text { selling handicrafts (fairs, events and fairs, street stall, } \\
\text { museum, tourist and cultural center, shops) }\end{array}$ & 9,018 & 4 & 0,018 \\
\hline 3. & $\begin{array}{l}\text { The ogranized production of handicrafts / The organized } \\
\text { distribution of local traditional foods and beverages }\end{array}$ & 6,519 & 1 & 0,011 \\
\hline 4. & $\begin{array}{l}\text { Form of organizing the producers of craft / The manner of } \\
\text { sale of handicrafts }\end{array}$ & 10,602 & 4 & 0,004 \\
\hline 5. & $\begin{array}{l}\text { The area ceded by the municipality / Organized sale of } \\
\text { handicrafts }\end{array}$ & 7,543 & 1 & 0,006 \\
\hline 6. & $\begin{array}{l}\text { The ogranized production of artifacts / Support local } \\
\text { governments to promote rural development (diversification } \\
\text { of economic activities) and rural development (including } \\
\text { tourism organization) }\end{array}$ & 8,278 & 2 & 0,006 \\
\hline 7. & $\begin{array}{l}\text { The manner of selling handicrafts / The ways of selling } \\
\text { local food and drink (fairs, events and fairs, street stall, } \\
\text { museum, tourist and cultural center, shops) }\end{array}$ & 15,000 & 4 & 0,005 \\
\hline 8. & $\begin{array}{l}\text { Is developed rural tourism / The level of development of } \\
\text { rural tourism }\end{array}$ & 6,519 & 1 & 0,011 \\
\hline 9. & $\begin{array}{l}\text { Organizing training / Support local governments to } \\
\text { promote rural development and rural development }\end{array}$ & 9,900 & 2 & 0,007 \\
\hline 10. & $\begin{array}{l}\text { Support local governments to promote rural development } \\
\text { and rural development / Utilization potential of the } \\
\text { municipality for rural development and rural tourism }\end{array}$ & 6,519 & 2 & 0,038 \\
\hline 11. & $\begin{array}{l}\text { Organized ways of producing handicrafts, traditional food } \\
\text { and drinks / The potential for development of rural tourism }\end{array}$ & 5,867 & 1 & 0,015 \\
\hline 12. & $\begin{array}{l}\text { Organized ways of selling handicrafts, traditional food } \\
\text { and drinks / Support local governments to promote rural } \\
\text { development and rural development }\end{array}$ & 6,875 & 2 & 0,032 \\
\hline
\end{tabular}

Source: Authors research 
Based on the analysis and processing of the collected data (Table 2), as the most important results of the research the following can be mentioned:

1. Using the chi-square test showed that the production techniques of handicrafts and form of organizing the producers of craft are dependent characteristics $(p<0.05)$. Those deling with embroidery are generally organized through associations $(85.7 \%)$ and those who are engaged in weaving are generally organized as individuals $(100 \%)$. Those involved in knitting are equally organized through associations, informal groups and as individual persons (respectively by $33.3 \%$ ).

2. Also, the techniques of making handicrafts and the manner of selling are the dependent features $(p<0.05)$. Those dealing with embroidery usually sell their products at fairs, events and exhibitions (100\%), those dealing with knitting alike sell their products at fairs, events and exhibitions and street stalls (by 42.9\%), and those dealing with weaving alike place their products on street stalls and museums, tourist and cultural centers (50\%).

3. The ogranized production of handicrafts and organized distribution of local traditional foods and beverages are dependent features $(p<0.05)$. In municipalities where there is no organized production of handicrafts, there is an organized sale of local traditional food and drinks $(100 \%)$, while those who are not involved in the organized sale of handicrafts generally have no organized sale of local food and beverages $(88.89 \%)$. This dependence indicates the complementarity of handicrafts and traditional food and drink.

4. There is a significant dependence between the organizational form of craft and the manner of sale of handicrafts $(p<0.05)$. All of which are organized in the form of associations, for the placement of their products use fairs, as well as events and exhibitions (100\%), whereas those which are organized in the form of an informal group for marketing their products use street stalls (100\%). Private individuals approximately equally use all three types of sales.

5. It was found that those who have the support of municipality in their work, generally have an organized sale of handicrafts $(80 \%)$, while those who do not have the support of the municipality have no organized sale of handicrafts $(100 \%)$.

6. Dependent features are organized sale of handicrafts and municipal support. In municipalities where there is an organized sale of handicrafts the municipal support is mostly excellent (75\%) and in municipalities where there is no organized sale of handicrafts, municipal support is mostly satisfactory $(85.7 \%)$.

7. Statistically significant dependence confirms the link between selling handicrafts and ways of selling local food and drink, and that in both cases the most common are fairs, events and trade fairs $(100 \%)$.

8. In municipalities where rural tourism is underdeveloped, the respondents have stated that the degree of development is poor (100\%) and where it is developed, they 
mainly stated that the degree of development is satisfactory (66.7\%). Given that no one has stated the excellent level of development, we can conclude that there is room for significant improvement.

9. Where there is a satisfactory support of the local administration, in $83.3 \%$ of the cases education is organized, which is in favor of further education and training of rural population.

10. In municipalities where support of the local administration is rated as insufficient or unsatisfactory, the respondents believe that the potential of the municipality for rural development and rural tourism is not utilized (100\%), but even in municipalities where there is great support from the local administration, the potential is not fully utilized, but only in two thirds of municipalities $(66,7 \%)$

11. There is a statistically significant relationship between organized ways of producing handicrafts, food and drinks with the potential of rural tourism development, and it in $40 \%$ of cases where there is organized production and the potential for development of rural tourism. Where there is no organized method of production, it was confirmed that there is no potential for development of rural tourism. Based on that, it can be concluded that the organized production of handicrafts using traditional crafts and production of traditional food and beverages is an essential prerequisite for the development of rural tourism.

12. Also confirmed is a statistically significant relationship between organized ways of selling handicrafts, traditional food and drinks with the support of local government. Where there is great support from the local governments, in $66.7 \%$ of the municipalities there is an organized sale of handicrafts, traditional food and drinks.

Based on the results, it can be concluded that there is a significant connection between the old trades and crafts and traditional food and beverages with rural development of the region and tourism. Sumadija and Pomoravlje region in addition to the geographical position occupying a central position in Serbia, and on this basis that it can realize significant benefits, by preservation and promotion of traditional values can be considered an extremely promising destination for rural tourism in the future. Development of rural tourism in the region can contribute to the economic development of the region and to lower fluctuation of the rural population, which multiplies the positive effects of investments in development and branding of destinations.

\section{Conclusion}

Despite the significant potential, rural tourism in the region of Šumadija and Pomoravlje, is not adequately utilized. The wealth of natural resources, anthropogenic values (traditional crafts, handicrafts, etc.), the original architecture of this part of Serbia, the possibility of authentic life in the countryside (fairs, gatherings, traditional gastronomy, etc.), are the real basis for the development of rural tourism, and the basis for the creation of a unique tourism product of the region of Šmadija and Pomoravlje. The development of rural tourism is achieved by 
revitalization of traditional and indigenous values, thereby activating a range of activities, services and additional contents organized by the rural population on family farms in order to attract tourists and create additional revenue, while respecting the principles of sustainable development and conservation of natural resources.

In order to position Šumadija and Pomoravlje region as a recognizable destination for rural tourism, it is necessary to create a stimulating environment and involve a larger number of local residents and economic entities in rural development and rural tourism in the region. Rural tourism can be a significant factor in the economic development of the villages of the region. For the future development of rural tourism in the region Sumadija and Pomoravlje, crucial are the institutional and economic support of state authorities and local governments, organization of thematic training and general education of the rural population, associating and better promotion. Such measures would allow the creation of a unique and recognizable regional destination brand, which would be based on the preservation of the traditional values of the region.

\section{References}

1. Boyne, S. (2005): New Directions in Rural Tourism Impact Research, in New Directions in Rural Tourism, Hall D., Roberts L. and Mitchell M.(eds), Ashgate Publishing Limited, pp.19-37, Aldershot, England.

2. Bradić, M., Kosar, Lj., Djeri, L., Vukosav, S., Garača, V. (2017): Eco-labelling of accommodation facilites and its perception by rural tourists: Case study of Vojvodina. Economics of Agriculture, The Balkan Scientific Association of Agrarian Economists, Belgrade, Institute of Agricultural Economics, Belgrade, Academy of Economic Studies, Bucharest, Vol. 64, No. 1, pp. 205-219, Belgrade.

3. Buhalis, D., Costa, C. (2006): Tourism business frontiers - Consumers, products and industry. (ISBN 075066377 4). Butterworth-Heinemann, Oxford.

4. Cozac, E. (2012): The importance of rural tourism development in rural communities, Fascucula: Ecotoxicologie, Zootehnie şi Tehnologii de Industrie Alimentară, Analele Universităţii din Oradea, pp. 19-22, Oradea, Jud. Bihor.

5. Čikić, J., Jovanović, T. (2015): Difuzija znanja i razvoj ruralnog turizma u Vojvodini. (ISBN 978-86-7031-383-5) . Prirodno matematički fakultet, Novi Sad.

6. Dimitrovski, D., Todorović, A., Valjarević, A. (2012): Rural tourism and regional development: Case study of development of ruraltourisam in the region Gruža, Procedia Environmental Sciences, Vol. 14, pp. 288 - 297, United Kingdom.

7. Đenadić, M., Muhi, B., Jovanović, D. (2016): Rural tourism-Serbia’s missed chance. Economics of Agriculture, The Balkan Scientific Association of Agrarian Economists, Belgrade, Institute of Agricultural Economics, Belgrade, Academy of Economic Studies, Bucharest, Vol. 63, No.2, pp. 515-529, Belgrade.

8. Fleischer, A., Pizam, A. (1997): Rural tourism in Israel. Tourism Management, Pergamon, Vol. 18, No. 6, pp. 367-372, Great Britain. 
9. Hrabovski Tomić, E., (2008): Selektivni oblici turizma. (ISBN 978-86-84529-40-6). Fakultet za uslužni biznis, Sremska Kamenica.

10. Košić, K. Demirović, D., Pejanović, R., Lazić, L., Stamenković, I. (2015): Key Principles of Rural Tourism Households Development Strategy - Case Study of Vojvodina. Economics of Agriculture, Vol. 62, No. 4, pp. 975-988, Belgrade.

11. Kotler, Ph., Gertner, D. (2002): Country as a brand, product, beyond: A place marketing and brand management perspective. Journal of Brand Management, Vol. 9, No. 4-5, pp. 250-251, United Kingdom.

12. Liu, C.Z. (2002): A Study on Leisure Agriculture and Rural Development. The Journal of Rural Development Perspectives, Vol. 3, pp. 19-33, The Social Sciences and Humanities Research Council of Canada, Ottawa, Canada.

13. Mandarić, M. (2016): Strategijski brend menadžment (ISBN 978-86-89949-179). Fakultet za hotelijerstvo i turizam u Vrnjačkoj Banji, Univerzitet u Kragujevcu, Vrnjačka Banja.

14. Mandarić, M., Milićević, S., (2016): Role and significance of tourism destinations branding. Book of proceedings of 3rd International Conference: "Higher education in function of development of tourism in Serbia and Western Balkans - SED 2016", 30 September - 01 October 2016, VPTŠ Užice, pp. 37-47, Užice.

15. Milićević, S., Đorđević, N. (2015): Potencijali za razvoj planine Goč kao destinacije ruralnog turizma. Ekonomija teorija i praksa, Univerzitet Privredna akademija, Fakultet za ekonomiju i inženjerski menadžment, Vol. 8, No.4, pp. 86-97, Novi Sad.

16. Milićević, S., Podovac, M., Čavlin, M. (2015): Resources for development of the Rača municipality as rural tourism destination. Economics of Agriculture, The Balkan Scientific Association of Agrarian Economists, Belgrade, Institute of Agricultural Economics, Belgrade, Academy of Economic Studies, Bucharest, Vol. 62, No. 3, pp. 751-765, Belgrade.

17. Ministarstvo privrede Republike Srbije. (2017): Sertifikacija starih zanata, (http:// www.privreda.gov.rs/ministarstvo/javnost-u-radu/usluge/seritifikacija-starih-zanata/)

18. Mitchell, M., Hall, D. (2005): Rural Tourism as Sustainable Business: Key Themes and Issues. in Rural Tourism and Sustainable Business, Hall D., Kirkpatrick I. and Mitchell M. (eds), Channel View Publications, pp. 3-14, Clevedon, Buffalo, Toronto, Canada.

19. Muhi, B. (2013): Ruralni turizam kao komponenta integrisanog i održivog razvoja sela $u$ Vojvodini. Zbornik Matice Srpske za društvene nauke, Matica Srpska, 142 (1/2013), pp. 129-137, Novi Sad.

20. Ristić, L., Vujičić, M., Leković, M. (2016): Tourism as a Factor of Sustainable Development of Rural Areas Belonging to Rudnicka Morava. Economics of Agriculture, The Balkan Scientific Association of Agrarian Economists, Belgrade, Institute of Agricultural Economics, Belgrade, Academy of Economic Studies, Bucharest, Vol. 63, No. 2, pp. 665-680, Belgrade. 
21. Regional Agency for Economic Development Šumadije and Pomoravlje. (2016): (http://www.redasp.rs/size-location-and-demographics.p33.html)

22. Statistical Office of the Republic of Serbia, Municipalities and regions of the Republic of Serbia. (2016): (http://pod2.stat.gov.rs/ObjavljenePublikacije/G2016/pdfE/ G20162020.pdf)

23. Statistical Office of the Republic of Serbia. (2012): Census of Agriculture 2012, Agriculture in the Republic of Serbia, (http://pod2.stat.gov.rs/ObjavljenePublikacije/ Popis2012/PP-knjiga2.pdf)

24. Saarinen, J., Lenao, M. (2014): Integrating tourism to rural development and planning in the developing world. Development Southern Africa, Vol. 31, No. 3, pp. 363-372, Taylor \& Francis Group, London, United Kingdom.

25. Schubert, S., Brida, J., Risso, W. (2011): The impacts of international tourism demand on economic growth of small economics dependent on tourism. Tourism Management, Vol. 32, No. 2, pp. 377-385, Pergamon, Oxford, United Kingdom.

26. Sekulić, D., Mandarić, M., Milovanović, V. (2016): Motivation of travelers for participation in wine tourism in Serbia. Economics of Agriculture, The Balkan Scientific Association of Agrarian Economists, Belgrade, Institute of Agricultural Economics, Belgrade, Academy of Economic Studies, Bucharest, Vol. 63, No. 4, pp. 1237-1253, Belgrade.

27. Sustainable Development Strategy for Šumadija and Pomoravlje Region, 2011-2021. (2011): Regional Agency for Economic Development Šumadije and Pomoravlje, (http://www.paracin.rs/files/sor.pdf)

28. Todorović, M., Štetić, S. (2009): Ruralni turizam. (ISBN 978-86-82657-76-7). Geografski fakultet u Beogradu, Belgrade.

29. Veljković, S. (2010): Brend menadžment (ISBN 978-86-403-1087-1). Centar za izdavačku delatnost Ekonomskog fakulteta u Beogradu, Belgrade.

30. Vuković, P., Arsić, S., Cvijanović, D. (2010): Konkurentnost ruralnih turističkih destinacija. Economics of Agriculture, The Balkan Scientific Association of Agrarian Economists, Belgrade, Institute of Agricultural Economics, Belgrade, Academy of Economic Studies, Bucharest, Vol. 57, No. 1, pp. 47-60, Belgrade.

31. Vuković P., Cecić, N., Cvijanović, D. (2007a): Održivi turistički razvoj ruralnih područja Srbije. Economics of Agriculture, The Balkan Scientific Association of Agrarian Economists, Belgrade, Institute of Agricultural Economics, Belgrade, Academy of Economic Studies, Bucharest, Vol. 54, No. 3, pp. 369-379, Beograd.

32. Vuković P., Cecić, N., Cvijanović, D. (2007b): Potencijali turističkog razvoja sela Glogonj. Ekonomika, Institute of Agricultural Economics, Vol. 53, No. 3-4, pp. 142150 , Belgrade.

33. World Toursm Organization. (2004): Rural Tourism Europe: Experience, Development and Perspectives. 


\title{
TRADICIONALNE VREDNOSTI U FUNKCIJI PROMOCIJE ŠUMADIJE I POMORAVLJA KAO DESTINACIJE RURALNOG TURIZMA
}

\author{
Marija Mandarič́, Snežana Milićevič́, Dejan Sekulič ${ }^{6}$
}

Rezime

Ruralni turizam $i$ diverzifikacija ekonomskih aktivnosti predstavljaju neodvojivi deo održivog razvoja ruralnih sredina regiona Šumadije i Pomoravlja. Razvoj ruralnog turizma unapređuje ekonomski položaj i društvenu aktivnost stanovništva ruralnog područja. Region Šumadije i Pomoravlja poseduje značajni prirodni i ljudski potencijal za razvoj ruralnog turizma koji nije adekvatno iskorišćen. Očuvanje autentičnih vrednosti podneblja, posebno tradicionalnih zanata i gastronomije, može da doprinese razvoju i prepoznatjivosti ove regije kao nove destinacije ruralnog turizma u Srbiji. Tradicionalni proizvodi zbog svog obeležja, kvaliteta i nasleđa, mogu postati regionalni brend, i takođe, promovisati region kao jedinstvenu destinaciju ruralnog turizma. Cilj rada je da istraži zastupljenost starih zanata, proizvodnje rukotvorina i tradicionalne gastronomije u regionu Šumadije i Pomoravlja. Rezultati sprovedenog istraživanje ukazaju na značajan i nedovoljno iskorišćen potencijal tradicionalnih vrednosti u razvoju i promociji ove regije kao ruralne turisticke destinacije.

Ključne reči: ruralni turizam, tradicionalne vrednosti, brendiranje, turistička destinacija, Šumadija i Pomoravlje.

4 Docent, dr Marija Mandarić, Univerzitet u Kragujevcu, Fakultet za hotelijerstvo i turizam u Vrnjačkoj Banji, Vojvođanska ulica bb, Vrnjačka Banja, Srbija, Telefon: +381642590099, E-mail: mmandaric@kg.ac.rs.

5 Docent, dr Snežana Milićević, Univerzitet u Kragujevcu, Fakultet za hotelijerstvo i turizam u Vrnjačkoj Banji, Vojvođanska ulica bb, 36210 Vrnjačka Banja, Srbija, Telefon: +381648198991, E-mail: snežana.milićević@kg.ac.rs.

6 Dejan Sekulić M.Sc., Asistent, Univerzitet u Kragujevcu, Fakultet za hotelijerstvo i turizam u Vrnjačkoj Banji, Vojvođanska ulica bb, 36210 Vrnjačka Banja, Srbija, Telefon: +38162602902, E-mail: dejan.sekulic@,kg.ac.rs.

EP 2017 (64) 2 (787-803) 